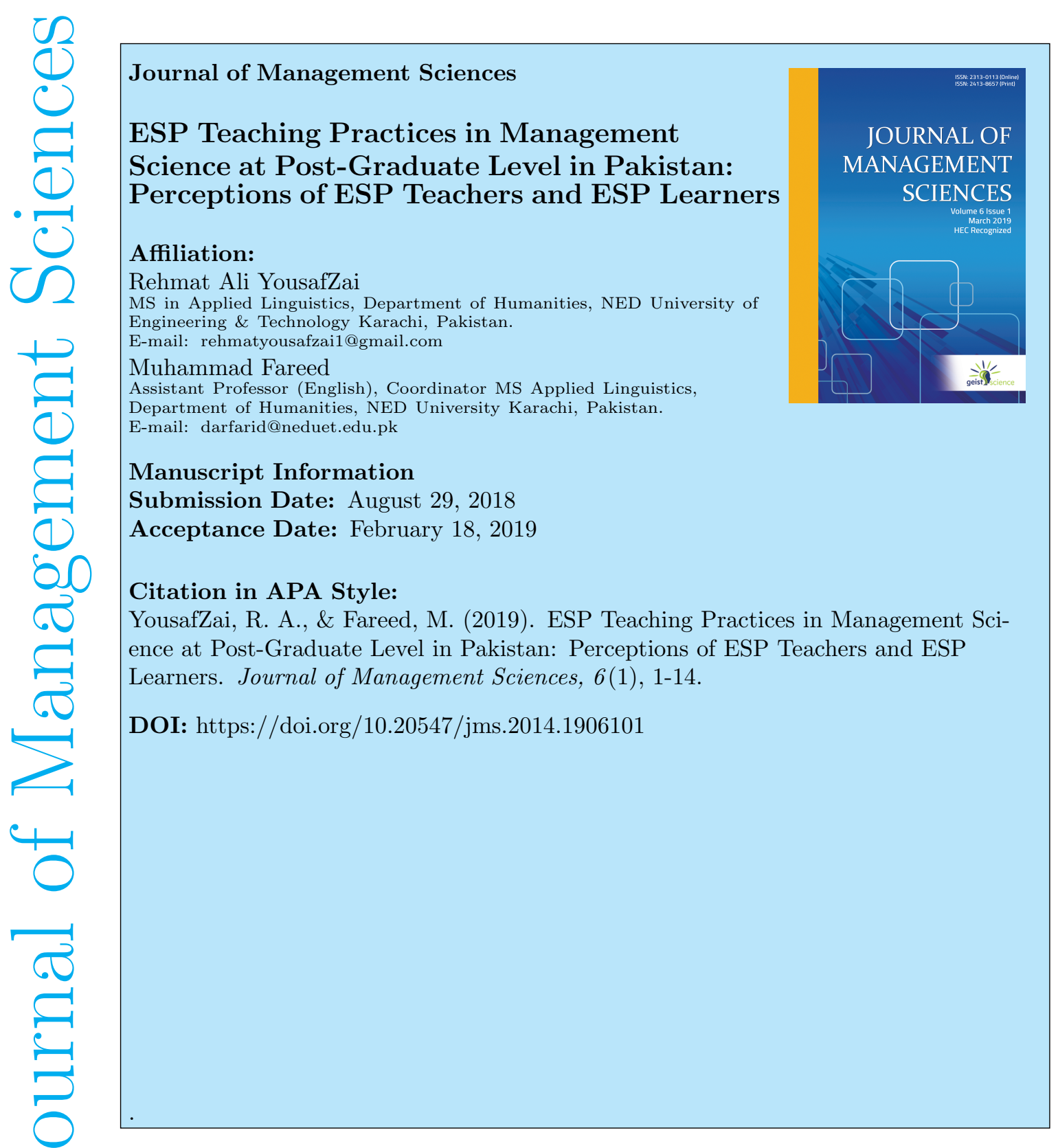




\title{
ESP Teaching Practices in Management Science at Post-Graduate Level in Pakistan: Perceptions of ESP Teachers and ESP Learners
}

\author{
Rehmat Ali YousafZai * $\quad$ Muhammad Fareed ${ }^{\dagger}$
}

\begin{abstract}
English for Specific Purposes (ESP) teaching is considered a separate activity in the domain of English Language Teaching (Dudley-Evans \& St John, 1998). ESP primarily aims to prepare and fulfill a set of the communicative needs of ESP learners in academic and professional contexts. These needs serve as a guide to design relevant course content and adopt appropriate teaching method with particular emphasis on the kind of English to be taught and the topics to be covered. The current study attempts to investigate through the perceptions of ESP teachers and ESP learners the effective role of Subject Matter Specialists (henceforth SMSs) in the teaching of ESP courses at postgraduate level in Pakistan. The sample size taken for this study comprises of 10 ESP teachers selected through snowball sampling technique and 50 ESP learners chosen through purpose sampling from three different disciplines of management sciences. Open ended questionnaire and interviews were used for data collection. The data were thematically analyzed. The analysis of ESP teachers' data suggested English language competence, pedagogic competence and awareness of the learners' prospective communicative needs in academic and workplace contexts. The analysis of ESP learners' data indicated that Subject Matter Specialists (henceforth SMSs) along with content area knowledge need to have good command of English language as well. From the comparative analyses of ESP teachers and ESP learners' data, this study concludes that for effective ESP teaching to any group of ESP learners, an ESP teacher irrespective of the academic background (ELTs or Subject Matter Specialists) needs to have English language competence, pedagogic skills and how much they know about the learners' target communicative needs.
\end{abstract}

Keywords: ESP Teaching, ESP teaching practices in Pakistan, ESP teachers, English language teachers (ELTs), Subject Matter Specialists (SMSs), ESP learners.

\section{Introduction}

The global significance of English language in the realms of science and technology, business and politics, media and education, governments and diplomacy has made English language a necessary tool of communication across the globe (Dar, Zaki, \& Kazmi, 2010; Zaki, 2007). Due to this significance, English has become the language of education, offices, administration, technology and research in Pakistan (Dar, Akhtar, \& Khalid, 2014; Atique \& Khan, 2015; Ali \& Khan, 2015; Dar \& Khan, 2014). Consequently, the teaching of English in Pakistan is no longer considered simply as an academic activity rather as the most potential way to help people in gaining access to social uplift and economic

\footnotetext{
*MS in Applied Linguistics, Department of Humanities, NED University of Engineering \& Technology Karachi, Pakistan. E-mail: rehmatyousafzai1@gmail.com

${ }^{\dagger}$ Assistant Professor (English), Coordinator MS Applied Linguistics, Department of Humanities, NED University Karachi,

Pakistan. E-mail: darfarid@neduet.edu.pk, mfareeddar@yahoo.com
} 
prosperity (Shamim, Khurram, Shahabuddin, \& Usmani, 2006; Shamim, 2007). English language teaching is not only restricted to social sciences but to other fields such as agriculture,economics, medicine, law and engineering as well (Channa, 2013; Ahmed, 2001; Ahmad, 2006). Thus alongside technical and professional skills, competence in English language is needed for effective communication in academic and professional contexts (Niazi, 2012; Liton, 2012). To achieve this purpose, students at tertiary level are taught ESP courses (Abdulaziz, Kazim, Mahmood, \& Fazal e Haq, 2012; Buriro \& Soomro, 2013; Niazi, 2012)

It is claimed that English language teachers (ELTs for short) do not have appropriate content area knowledge of the ESP learners majoring in commerce, engineering or medicine. Consequently in ESP teaching, ELTs face difficulties in the teaching of genres having technical language repertoire (Hamp Lyons, 2001). Other studies however suggest that Subject Matter Specialists (SMSs) although possess sufficient subject area knowledge but are unprepared to decode language related concepts clearly that could help students in developing their language skills for oral and written communication (Qazi \& Simon, 2012; Niazi, 2012; Buriro \& Soomro, 2013; Bojovic, 2006).

The current study explores the perceptions of ESP teachers and ESP learners in management sciences with the intent to know the effectiveness of Subject Matter Specialists (SMSs) in the teaching of ESP courses at tertiary level in Pakistan.

\section{Rationale of the Study}

It is claimed that ESP is primarily a branch of English language teaching. It aims to provide ESP learners with requisite English language skills in order to carryout written and oral communication in academic as well in professional communicative situations (Orr, 2002). Research suggests that ESP teachers who don't have content area knowledge of the learners' field of study are not qualified to teach ESP courses effectively (Strevens, 1988). Hutchinson and Waters (1987) however suggest that ESP teachers don't need to have content specific knowledge, rather for effective ESP teaching the teachers should have: (a) positive attitude towards the ESP content, (b) knowledge of the fundamental principles of the subject area, and (c) an awareness of how much they probably know. In the realm of business, commerce, medicine, engineering and industry, different areas have been researched in the field of ESP in Pakistan (Massood, 2003; Bashir, 2004; Imtiaz, 2002; Niazi, 2012). These studies have mainly focused on needs analysis, syllabus designing and material development for students of medicine, engineering and commerce. No study was found to have probed the ESP teaching phenomenon at tertiary level with particular emphasis on the role of ESP teachers. With this as a backdrop, such theoretical underpinnings provide the rationale to fill this research gap by exploring the ESP teaching practices of Subject Matter Specialists in the context of this study. 


\section{Review of the Related Literature}

English for specific purposes (ESP), a subfield of English Language Teaching is defined as the development of teaching materials and methods appropriate for the ESP learners whose main goal is learning English for a purpose rather than just learning the language system (Maleki, 2008). ESP aims to prepare learners to communicate effectively in the tasks prescribed by their field of study or work situation (Hull, 2004, 2006; Robinson, 1991). According to (Hutchinson \& Waters, 1987) "ESP is an approach to language teaching in which all decisions as to the content and method are based on the learner's reason for learning".

Since language is a context specific entity, arguably the contents and methods of ESP teaching also vary to meet the specific needs of learners in target situations (Hutchinson \& Waters, 1987). The four widely used methods in ESP teaching are: a) content-based approach, "a kind of the teaching approach in which the content has sufficient language information that the learners are learning with little or no direct or explicit efforts " (Richards, 2001), b) task-based approach, "an approach to language teaching organized around tasks rather than language structures" (Nunan, 2004), c) lexical-based approach, "an approach to language teaching based on the concept that the basic building blocks of teaching and learning are words and lexical phrases rather than grammar, functions or other units of organization" (Richards, 2001) and d) content and language integrated learning (CLIL) method. CLIL is an integrated approach with methodology used to incorporate the elements of language and content as well (Savic, 2010).

Since ESP is not a static entity; as such the content and method of teaching in ESP courses also vary according to the learners' needs. Dudley-Evans and St John (1998) have preferably used the term 'practitioner' because the tasks in ESP are more than teaching. Accordingly the ESP practitioner has five key roles to perform: teacher, course designer and material provider, collaborator, researcher and evaluator. ESP is an entirely learnercentered and goal-oriented approach in English language teaching, a greater responsibility is thus imposed on ESP teachers to prepare students for the target communicative needs (Basturkmen, 2005). Thomson (1993) suggests that effectiveness in ESP teaching is based on four competencies: language competence, pedagogic competence, language awareness and specialized knowledge. The ESP teachers with such competencies attempt to employ alternative instructional methods and techniques appropriate to the learners' target needs.

Concerning the effective role of ESP teachers, Wilkins (1976) suggests, it seems improbable to expect a teacher to set objectives for which he or she him/herself is not prepared to teach. He further claims that the best curriculum and a perfect syllabus remain dead unless the right approach to the right kind of teaching is not adopted. Various studies of (Strevens, 1988)(Strevens, 1988; Swales, 1988; Pholsward \& Allen, 1988) as well as insights from genre studies (Swales, 1988; Freedman \& Medway, 1994), and schema theory (Cohen et al., 1988) suggest that difficulties in ESP teaching may be due to unfamiliarity with professional genre forms and discourse conventions, their purpose and function, as well as the values systems that underlie the discourse in various fields. For effective ESP teaching, Hutchinson and Waters (1987) suggest that ESP teachers need to have: (a) 
a positive attitude towards the ESP content, (b) knowledge of fundamental principles of the subject area, and (c) an awareness of how much they probably already know.

\section{Methodology}

Based on the perceptions of ESP teachers and ESP learners, this qualitative descriptive study was conducted to explore the ESP teaching practices in management sciences at postgraduate level in Karachi.

\section{Participants}

The sample of the study comprised fifty ESP learners both male $(n=20)$ and female $(n=30)$ majoring in MBA HRM, MBA Finance and MBA Accounts and ten (10) ESP teachers (SMSs). The study used snowball sampling in selecting ESP teachers and purposive sampling in choosing ESP learners (Cohen, Manion, \& Morrison, 2007). Phenomenological research design was used to probe the lived experiences of ESP teachers and ESP learners. A phenomenological inquiry is the kind of research which attempts to probe the inner experiences of individuals about the phenomenon un-probed in everyday life (Merriam, 1988). Table 1 presents sample distribution of the participants.

Table 1

Sample Distributions of the Participants

\begin{tabular}{lcccc}
\hline \multicolumn{1}{c}{ Main Group } & Sample & \multicolumn{2}{c}{ Subgroups } \\
\hline (a) ESP Teachers & 10 & \multicolumn{2}{c}{$\begin{array}{c}\text { Male } \\
6\end{array}$} & $\begin{array}{c}\text { Female } \\
4\end{array}$ \\
\hline Subgroups & & & & \\
\hline (b) ESP Learners & 50 & $\begin{array}{c}\text { MBA HRM } \\
17\end{array}$ & $\begin{array}{c}\text { MBA Finance } \\
18\end{array}$ & $\begin{array}{c}\text { MBA Accounts } \\
15\end{array}$ \\
\hline
\end{tabular}

\section{Instruments}

The current study used interview protocols and open ended questionnaires in data collection, which were developed by the researchers. The interview schedule contained fourteen items were meant for the ESP teachers. The questionnaire has ten items were administered to ESP learners. Prior to data collection, validity of the instrument was achieved. Validity means, the extent to which an instrument appropriately measures what it claims to measure (Cohen et al., 2007). The following procedure was used in instrument validation.

\section{Self Validation}

After developing the tool, the researcher himself reflected to know whether each item in the instrument adequately measure what it was meant to measure. 


\section{Expert Validation}

The tool after self-validation was sent to five experts in the field (validation jury).The suggested emendation by jury in the tool were made by the researcher with the intent to make the instrument refined and valid)

\section{Pilot Validity}

An empirical test of the instrument was then conducted in the field. This involved testing participants who were not sample of the main study. Reliability of the instrument was ensured by examining consistency in responses of the participants participated in pilot study.

\section{Procedure}

This study was conducted at two private sector institutes and one public sector university of Karachi. The data were collected in two phases. In first phase, individual semi structured interviews were conducted with ESP teachers (SMSs). The interviews were audio recorded. The recorded interviews were uploaded to portable devices for transcription and safety as well. The transcriptions of interviews were then emailed to all interviewees for respondents' validation. To ensure anonymity of the participants, pseudonym MSMSs with numeral 1 to 6 was used for male Subject Matter Specialists. Female subject matter specialists were assigned FSMSs with numeral 1 to 4 . In the second phase, open ended questionnaires were administered to ESP learners. Codes were also assigned to each group representing a particular discipline: HRM ESP learners were assigned HR with numeral 1 to 17, Finance group were given F with numeral 1 to 18 and Accounts group were assigned A with numeral 1 to 15. Prior to data collection, a written consent was obtained by signing an agreement statement from each participant.

\section{Data Analysis}

Saldana (2011) recommends in-depth description of coding processes for qualitative research. Thus a constant comparative analysis of the data collected through semi-structured interviews and open ended questionnaires was carried out through open coding (Glaser \& Strauss, 1967). This was followed by pattern coding Saldana (2011) which refers to a process of repeated sifting through the data to distinguish similarities and patterns. The analyses of similarities and patterns in data gradually led to evolving categories. These repetitive processes continued until a saturation of the data was achieved.

\section{Coding Scheme of ESP Teachers' Data}

The following table presents coding scheme of ESP teachers' data. 
Table 2

Coding scheme to categorize ESP Teachers' comments about teaching Experience

Category ESP Teachers Sample Comments

a) ESP Courses Taught

English for business communication, English for nursing, English for medicine, English for lawyers, English for engineers,

Managerial communication, Technical report writing and presentation skills, Academic writing, Progress report writing,

Oral communication and Communication skills

b) ESP teaching experience

5 SMS interesting

3 SMS challenging

2 SMS a new learning and teaching experience

c) Problems of the ESP learners experienced by ESP Teachers

3 SMS students' lack of awareness about the course

7 SMS students' poor English language proficiency

d) Coping strategies used by the teachers

3 SMS grouping weaker students with sharp students

4 SMS practices through group and individual task

3 SMS peer feedback for written and presentation skills and also teacher feedback and guidance

e) ESP teacher teaching method

1 SMS case studies

2 SMS lecture followed by tasks

3 SMS tasks, quizzes and assignments

4 SMS mostly tasks and activities

f) ESP teaching materials

9 SMS combination of books and authentic materials

1 SMS books and case studies

g) Assessment procedure

10 SMS Formative assessment based on special grids for grading in tests, assignments, and presentations and summative assessments through exams

h) Challenges of ESP teachers

9 SMS subject area knowledge without good command of English language is difficult

1 SMS teacher's difficulties in teaching

\section{Thematic Analysis of ESP Teachers' Data}

\section{Theme 1: ESP Teaching Experiences of Subject Matter Specialist (SMSs)}

The analyses of five ESP teachers' data (50\%) suggested ESP teaching an interesting experience (MSMS2; FSMS4). For three ESP teachers(30\%), it was challenging (FSMS1; MSMS5). The other two (20\%), found it a new learning and teaching experience (FSMS2; MSMS3).

\section{Theme 2: Problems of the ESP Learners}

The analyses of seven ESP teachers' data (70\%) suggested students' poor English language proficiency (MSMS, 1; MSMS, 2). The data of three ESP teachers (30\%) have shown students' lack of awareness about the ESP course (FSMS,2; MSMS,3; FSMS,4)..

\section{Theme 3: Coping Strategies used by ESP Teachers}

In an attempt to make learning easier, the analyses of three ESP teachers' data(30\%) suggested group activities and peer work i.e. pairing weaker students with sharp stu- 
dents(MSMS1; FSMS4).From the analyses four ESP teachers' data(40\%), it was found that both group activities and individual tasks were used in ESP teaching (FSMS2; FSMS3). The remaining ( $30 \%$ data) suggested peer feedback for written and presentations for oral skills were the most preferred techniques used frequently (MSMS2; MSMS5).

\section{Theme 4: Teaching Method used by ESP Teacher}

Concerning ESP teachers' style and method of teaching, the analysis of data (20\%) suggested the use of case studies (FSMS2). The analysis of two ESP teachers' data (20\%) have pointed mixed method approach i.e. lecture followed by tasks (MSMS3; FSMS1, and (60\%) data revealed tasks, quizzes and assignments (FSMS4; MSMS2\&5).

\section{Theme 5: ESP Teaching Materials}

Regarding the kind of materials used in ESP teaching, the analysis of nine ESP teachers' data $(90 \%)$ suggested authentic materials and books as well. It was also found that the prescribed books are so alien to students to be interpreted. Materials are developed from variety of sources according to the learners' prospective communicative needs (MSMS2\&3; FSMS1\&4). The remaining $(10 \%)$ data revealed the use of books and case studies in ESP teaching (MSMS, 5).

\section{Theme 6: Assessment Procedure used in ESP Teaching}

The analyses ESP teachers' data (100\%) suggested formative assessment based on special grids for grading in tests, assignments and presentations followed by summative assessments conducted through term exams at the end of the semester (MSMSs1, 2\&5; FSMS1, $2,3 \& 5)$.

\section{Theme 7: Challenges of ESP Teachers}

Exploring the difficulties of Subject Matter Specialists in ESP teaching, the analyses of $(90 \%)$ SMSs' data suggested that an ESP teacher having mere content area knowledge without good command of English language would never help them to teach ESP effectively. In an attempt to prepare students for effective communication in oral, written, academic and professional contexts, the ESP teachers teaching ESP to any bench of learners are required to have good command of English language as well. As such along with subject area knowledge, the ESP teachers need to have some courses in linguistics to teach technical language aspects academically (MSMS1, 2, 3\& FSMS 1, 3\&4). The analysis of (10\%)data suggested teachers' personal difficulties in making adjustment to ESP teaching (MSMS, 5).

\section{Coding Scheme of ESP Learners' Data}

The following table presents the coding scheme of business and management ESP learners' data. 
Table 3

Coding scheme to Categorize Business and Management ESP learners' Comments about their learning Experiences

Category Numbers Sample Comments

a) ESP Courses

English for business communication, managerial communication, oral communication, memos, letters,

report writing, communication skills and presentation skills

b) Learning Experience

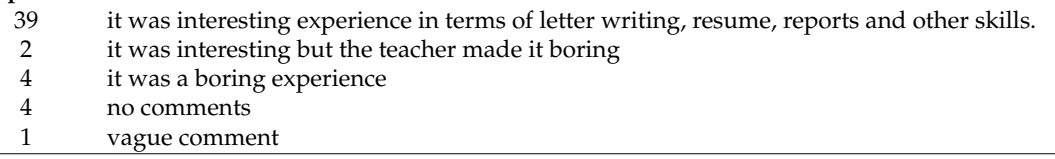

c) Problems in ESP Learning

34 poor English language backgrounds

10 lack of interest

2 lack of interest by the teacher

4 lack of awareness about the course

d) ESP teacher' teaching strategies

$40 \quad$ task and activities

6 assignments and case studies

4 vague comments due to poor writing

e) ESP teaching materials

23 the materials are designed by the teacher

21 books and self deigned materials by the teacher

3 vague comments

3 no answer

f) ESP course be taught by ELT or by a teacher from your field

10 by both ELTs and subject teacher

14 ELTs

4 anyone can teach

20 Subject Matter Specialists

2 no answer

\section{Thematic Analysis ESP Learners' Data}

\section{Theme 1: Learners' Experiences of the ESP Courses}

The analysis of ESP learners' data (76\%) revealed "ESP was interesting experience in terms of letter writing, resume, reports and other skills" (HR, 1; F, 2; HR, 9; A, 11). Four participants $(8 \%)$ called it boring experience (HR, 17; $\mathrm{HR}, 23 ; \mathrm{A}, 24 ; \mathrm{F}, 26)$. The other four participants $(8 \%)$ by expressing their dissatisfaction revealed that ESP was interesting but the teacher made it boring $(A, 5 ; H R, 10)$. Four participants couldn't write any response.

\section{Theme 2: Problems in ESP Learning}

In the analysis, 34 participants (68\%) revealed: "we have poor English language background" (HR, 1; F, 3; A, 5). Ten participants (20\%) expressed their lack of interest in the ESP courses (A, 2; F, 11; HR, 15; F, 17). The other two respondents (4\%) held that teacher was not interested in teaching $(\mathrm{HR}, 18 ; \mathrm{A}, 21)$. The responses of four participants $(8 \%)$ suggested ignorance about the significance of the ESP course taught as part of the syllabus (HR, 4; F, 23; A, 24) 


\section{Theme 3: Teaching Strategies used by Teacher}

The analyses of data (80\%) have shown teacher's reliance on activities and practical tasks (HR, 1; F, 24; A, 39). The responses of four participants $(8 \%)$ were vague due to poor writing and the other six participants $(12 \%)$ pointed the use of case studies.

\section{Theme 4: ESP Teaching Materials}

Twenty three participants $(46 \%)$ revealed that mostly the materials are prepared by the teacher $(\mathrm{HR}, 1 ; \mathrm{A}, 2 ; \mathrm{F}, 7$; HR, 16). Twenty one participants $(42 \%)$ revealed that books as well as self-designed materials are used by the teacher. Three participants $(6 \%)$ couldn't write any answer and the responses of three other participants $(6 \%)$ couldn't be interpreted due to vague writing.

\section{Theme 5: Preference for ESP Teacher}

The analyses have shown ten participants' views (20\%) who suggested that ESP should be taught by both ELTs and Subject Matter Specialists: "team teaching would be better" (HR, 3; F, 34; A, 41), fourteen participants (28\%) preferred ELTs (HR, 4; A, 7 \&F, 11) and 20 participants (40\%) preferred SMSs for ESP teaching (HR, 13; F, 19; A, 45).Four participants $(16 \%)$ have suggested that anyone can teach ESP courses (HR, 27; F, 33); two participants $(4 \%)$ had no responses.

\section{Findings}

\section{ESP Teachers' Data}

The ESP teaching practices of Subject Matters Specialists in eight domains were explored. From the analysis of data, the following conclusions have been drawn: The analysis of Subject Matters Specialists' data suggested that ESP teachers alongside content area knowledge and good pedagogical skills need to have good command of English language as well. It was also found that an ESP teacher who teaches ESP, specialty of the learners' field of study is not a necessary condition because ESP is neither a matter of the specialization of language nor the specialization of the content rather it is an orientation, more of a partnership between the teacher and the students. In ESP, the focus is not on content but on generic skills related to the content in order to prepare learners for the target situation needs. As such the teacher with right orientation can do a better job than either by ELTs or Subject Matter Specialists. These findings are consistent with previous studies conducted "ESP learning should be a shared process based on the teacher's pedagogy and competence in language and the learner's subject area knowledge (Maleki, 2008; Zoghi \& Farsi, 2014; Estaji \& Nazari, 2015). 


\section{ESP Learners' Data}

This study explored the perceptions of ESP learners with the intent to know the effectiveness of Subject Matter Specialists in ESP teaching, the following conclusions have been drawn: The analysis of ESP learners' data (40\%) preferred Subject Matter Specialists, $28 \%$ were in favor of ELTs, $20 \%$ preferred both ELTs and Subject Matter Specialists, and 8\% commented that anyone can teach, $4 \%$ gave no comments.

\section{Discussion}

The findings of this study have yielded valuable insights. In all individual semi structured interviews, the ESP teachers were asked to figure out their views with respect to ESP teaching. It is worth mentioning that in each domain they were asked, the participants' responses suggested a pragmatic approach with respect to the strengths and weaknesses in the domain of ESP teaching. The discussion of the findings is as follows: Teachers who tend to regard ESP teaching an interesting experience was not based on their specialty of the learners' field but the expertise they had developed over years in ESP teaching. While suggesting the need of English language proficiency in ESP teaching, Subject Matter Specialists emphasized: "If you are from the discipline other than English and you are teaching ESP to any group of learners let say teaching to MBAs HRM, Accounts, Finance etc. you need to have good command of English language as well" (MSMS, 2; FSMS, 1). It was also found that specialty of the learners' field is not a necessary condition in ESP teaching. "for a Subject Matter Specialists that teach ESP, not necessarily he should be a master in linguistics or in literature nor he or should have the specialty of the learners' field of study but the teacher must have some training to acquire perquisite literacy for better language aspects to teach" (FSMS, 2\& FSMS, 4). This concurs with the findings of Abdulaziz et al. (2012) which shows $66 \%$ of the ESP practitioners in Pakistan are not formally trained for ESP teaching. The findings of this study further suggest that for ESP teacher mere subject area knowledge without having adequate command of English wouldn't yield the required learning outcomes. Thus for effective ESP teaching, alongside content knowledge, Subject Matter Specialists also need to have English Language Competence and Pedagogical skills as well. The findings of this study also suggest team teaching i.e. collaboration between ELTs and Subject Matter Specialists.

\section{Pedagogical Implications}

Concerning the ESP teaching practices in management sciences, the data gleaned from Subject Matter Specialists and ESP learners suggested that an ESP teacher irrespective of the backgrounds i.e. ELTs or non ELTs can teach ESP courses given the teachers can have three competencies: language competence, pedagogic competence and how much they know about the learners' target communicative needs (Estaji \& Nazari, 2015; Zoghi \& Farsi, 2014; Rajabi, Kiany, \& Maftoon, 2011). The findings of this study are concurrent with previous studies. This study found the significance of language competence 'a 
teacher with good subject knowledge but poor language skills will not be able to make his assessment transparent regarding the students' achievement in writing and oral communication skills'. This study also found that a pedagogically competent teacher will make his ideas across among the students by employing alternative teaching strategies. To make students communicate effectively in the target situation, an ESP teacher need to develop a certain level of knowledge of the learners' area of study as well.

\section{Conclusion}

This qualitative descriptive study has probed the ESP teaching phenomenon from the perspectives of ESP teachers and ESP learners. The comparative analyses of ESP teachers and ESP learners' data suggest that Subject Matter Specialists along with content knowledge need to have good command of English language as well (Alsolami, 2014; Estaji \& Nazari, 2015). From the comparative analyses of ESP teachers and ESP learners' data, it can be concluded that ESP teachers irrespective of the background (ELTs or Subject Matter Specialists) need to have language competence, pedagogic skill and how much they know about the ESP learners' target communicative needs in academic and professional contexts. As such the findings of the study are synonymous with those of Alsolami (2014), in which $80 \%$ of the teachers believed that ESP teachers should have a specialized knowledge about the learners' field of study. The findings of this study are claimed to provide useful insights with regard to the significance of ESP teachers' knowledge of language, pedagogy and awareness of the learners' target communicative needs. The insights from the finding and pedagogic implications of this study will provide guidance to other researchers interested in probing other aspects that come in the purview of ESP. In this regard, it will also serve as a related study for other researchers dealing with other factors in the teaching of ESP courses that might have been neglected in this research. 


\section{References}

Abdulaziz, M., Kazim, S., Shah, Mahmood, R., \& Fazal e Haq, H. M. (2012). Change from a general English teacher to an ESP practitioner: Issues and challenges in Pakistan. Interdisciplinary Journal of Contemporary Research in Business, 4(1), 434-465.

Ahmad, N. (2006). Legal English - A Case for ESP, PhD Thesis, Department of English (Unpublished doctoral dissertation). Bahauddin Zakariya University, Pakistan.

Ahmed, N. (2001). English for Agriculture: A Case of ESP (Unpublished doctoral dissertation). Unpublished PhD thesis, Bahauddin Zakariya University, Pakistan.

Ali, M., \& Khan, I. (2015). Teachers' perceptions regarding the factors affecting English essay writing of O Level students. Journal of Education $\mathcal{E}$ Social Sciences, 3(1), 173 197.

Alsolami, E. (2014). Barriers to teaching English for specific purpose among EGP teachers in the ELI. English for Specific Purposes World, 42(15), 1-23.

Atique, S. S., \& Khan, I. (2015). The Writing needs of Business Students: A Teacher's Perception in an EFL context. Journal of Education $\mathcal{E}$ Social Sciences, 3(2), 231-244.

Bashir, S. (2004). Using learners produced corpus to teach term paper writing to the MBA students (Master's thesis) (Unpublished doctoral dissertation). BahauddinZakariya University, Multan.

Basturkmen, H. (2005). Ideas and Options in English for Specific Purposes (ESL E Applied Linguistics Professional). London:Rutledge Press.

Bojovic, M. (2006). Teaching foreign languages for specific purposes: Teacher development. doi: http:/ / www.pef.uni-lj.si/atee/978-961-6637-06-0/487-493.pdf

Buriro, G. S., \& Soomro, A. F. (2013). Assessing the Academic Literacy and Learning Needs of Undergraduate Engineering Students at Quaid-e-Awam University of Engineering, Science and Technology (QUEST) Pakistan. Journal of Research $\mathcal{E}$ Reflections in Education (JRRE), 7(2), 83-96.

Channa, M. A. (2013). A study of needs, problems and wants of using English of Engineering students at Quaid-e-Awam University of Engineering. Science and Technology, Pakistan. Journal of Education and Practice, 4(3), 18-26.

Cohen, L., Manion, L., \& Morrison, K. (2007). Research Methods in Education. Routledge.

Dar, M. F., Akhtar, H., \& Khalid, H. (2014). Code-switching in Pakistani English language classrooms: Perceptions of English language teachers. Journal of Social Sciences and Interdisciplinary Research, 2(2), 16-26.

Dar, M. F., \& Khan, I. (2014). Oral communication apprehension among undergraduate engineering students in Pakistan. Journal of Education $\mathcal{E}$ Social Sciences, 2(2), 144-153.

Dar, M. F., Zaki, S., \& Kazmi, H. H. (2010). Students' reactions regarding the use of process strategy for oral presentation in ESP. English Language and Literary Forum, 12(1), 2-12.

Dudley-Evans, T., \& St John, M. J. (1998). Developments in English for specific purposes: A multi-disciplinary approach. Cambridge university press.

Estaji, M., \& Nazari, N. (2015). Exploring instructors' conceptions about EGP teacher challenges for becoming an ESP instructor in Iran: A qualitative study. English for Specific Purposes World, 46, 1-18. 
Glaser, B. G., \& Strauss, A. L. (1967). The discovery of grounded theory: Strategies for qualitative research. Chicago: Aldine.

Hamp Lyons, L. (2001). English for academic purposes. In: Carter, R., Nunan, D. (EDS.). Teaching English to Specific Purposes, 12(2), 145-157.

Hull, M. (2004). Changing the paradigm for Medical English language teaching.Paper presented at the 2004 International Symposium of English for Medical Purposes. Xi'an, China.

Hull, M. (2006). Whose needs are we serving: how is the design of curriculum for English for medical purposes decided. Beijing, China.

Hutchinson, T., \& Waters, A. (1987). English for specific purposes. Cambridge University Press.

Imtiaz, A. (2002). Business communication and report writing for M.Com banking students in Pakistan: A case study (M.Phil. dissertation). (Unpublished doctoral dissertation). BahauddinZakariya University, Multan, Pakistan.

Liton, H. A. (2012). Developing EFL teaching and learning practices in Saudi colleges: A review. Online Submission, 5(2), 129-152.

Maleki, A. (2008). ESP teaching: A matter of controversy. ESP World, 1, 17.

Massood, Z. (2003). Assessing the English language needs of medical students for presenting case histories (Master's thesis). (Unpublished doctoral dissertation). BahauddinZakariya University, Multan.

Merriam, S. B. (1988). Case study research in education: A qualitative approach. Jossey-Bass.

Niazi, M. M. (2012). English for medical purposes: A case of english for specific purposes (Unpublished doctoral dissertation). National University Of Modern Languages, Islamabad.

Nunan, D. (2004). Task-based language teaching. Cambridge: Cambridge University Press.

Orr, T. (2002). The nature of English for specific purposes. English for specific purposes, $1-3$.

Qazi, W., \& Simon, H. C. (2012). Effect of teaching methodologies for business communication at BBA level in a Pakistani classroom. European Journal of Scientific Research, 71(1), 72-77.

Rajabi, P., Kiany, G. R., \& Maftoon, P. (2011). Iranian English Major vs. Subject-matter ESP Teachers 'Beliefs and Instructional Practices in ESP Classes: A Comparative Study.

Richards, J. C. (2001). Curriculum development in language teaching. Cambridge University Press.

Robinson, P. C. (1991). ESP today: A practitioner's guide. Prentice Hall Hemel Hempstead.

Saldana, J. (2011). Fundamentals of qualitative research. OUP USA.

Savic, V. (2010). Are we ready for implementing CLIL in Primary language classrooms? British Council Serbia ELTA Newsletter, May.

Shamim, F. (2007). Sustainability of ESP projects: A case study from Pakistan. (Unpublished doctoral dissertation). Paper presented at the IATEFL Conference, Aberdeen, 19-22 April 2007.

Shamim, F., Khurram, B., Shahabuddin, F., \& Usmani, W. (2006). Case Studies of Organization of Teaching of English in Public Sector Universities in Pakistan. Report submitted to National Committee on English. Higher Education Commission: Islamabad. 
Strevens, P. (1988). ESP after twenty years: A reappraisal. ESP: State of the Art.

Zaki, S. (2007). English for specific purposes: Implications in medical education. Journal of the College of Physicians and Surgeons-Pakistan: JCPSP, 17(1), 1-2.

Zoghi, M., \& Farsi, S. (2014). Addressing the Dilemma in ESP Teaching: The English Language Teacher or the Subject-matter Specialist. Journal of Language and Translation, $4(1), 35-40$. 